\title{
Gender Differences in Research Scholarship among Academics: An International Comparative Perspective
}

\author{
Jisun Jung (The University of Hong Kong)
}

\section{Introduction}

An international comparative survey titled 'The Changing Academic Profession (CAP)' was conducted in 1992 and 2008 and shows considerable changes in the demographic distribution of academics. In particular, the proportion of female academics in 2008 is shown to have increased in all participating countries, compared with the 1992 CAP survey data. Overall, the rising fraction of female academics was a common change in all of the countries surveyed. For instance, the figure improved from eight percent to around seventeen percent in Japan, which has the lowest proportion of female academics (Arimoto, 2008). As well, the proportion of academic women in the USA rose from 36 percent to 42 percent (Finkelstein \& Cummings, 2008). In fact, the distribution pattern of female academics showed significant differences across nineteen higher-education systems in 2008 CAP survey. The proportion of female academics was 59 percent in Argentina and 57 percent in Australia, while that proportion was only seventeen percent in Japan and eighteen percent in Korea.

Demographic factors, including gender, have been frequently observed as an only control variable in many studies regarding academics issues (Teodorescu, 2000; Horta et al., 2012). However, as Keller (2001) points out, a demographic is one of the most important variables at individual and institutional level for deciding academic issues such as their teaching and research activities and reward system for them. In particular, gender is a powerful factor not only in terms of pathways to particular professions but also in relation to process operating within workplace practices, such as discrimination screening and opportunities for promotion (Poole et. al., 1997).

The interest in gender issues in academia was tied up with minority issues in USA. Initially, these issues were mainly related to topics of discrimination in terms of employment barriers and the salary gap between male and female academics (Toutkoushian \& Bellas, 2003). As well, there have been substantial empirical studies regarding the differences in scholarship between male and female academics (Bellas \& Toutkoushian, 1999). Previous literature about gender issues can be summarized as looking into several of these issues. First of all, many studies, including one by Bellas (1994), have proven that there is an unequal job market for female academics. Second, beyond mere hiring issues, some studies have proven that women remain disadvantaged in terms of promotion, tenure, and salary (Bellas, 1997; Preffer \& Davis-Blake, 1987). Third, studies have shown that there exist practical barriers for female academics, such as family and children (Gmelch, Wilke, \& Lovrich, 1986). In addition, regarding the above issues, female academics have lower jab satisfaction and higher stress (Hagedorn \& Sax, 1999). Fourth, empirical studies have shown that the teaching and research activities of women are different from those of male academics. The most common finding was that female academics are much more involved in teaching activities, while their 
research performance is lower than that of male academics (Sax et al., 1999). There have been different perspectives to explain this relationship in terms of teaching effectiveness and research productivity between male and female academics. For instance, Pole et al. (1997) gives example of that female academics are more person-oriented and that they value social, communication and interaction patterns associated with teaching. On the other hand, Olsen et al. (1995) suggest that the gender differences are not so much merely a matter of personal preference and orientation but are equally a product of institutional requests or demands. Finally, there have been recent studies concerning management and governance issues, such as the decision-making participation of female academics in university and a lack of female academics in high positions, an issue related to the "glass ceiling." As such, women still have limited opportunities to formulate university policies as presidents, vice presidents, academic deans, and department chairs (Bornstein, 2008).

Among these issues, this study focuses on how research scholarship is different between male and female academics. For this purpose, this study assumes, firstly, that gender issues in academia are different according to each higher education system. Therefore, this study includes cases in five countries (Australia, Brazil, China, England, and United States) in order to observe if the results are similar across different systems. Second, this study explores in detail the differences in research scholarship between male and female academics. Third, this study raises additional questions, such as 1) "Is research productivity among female academics generally lower than that of male academics?" 2) "Is this difference simply a gender issue or are their contextual factors that are more important?" and 3) "Does it come from their individual profile or academic discipline?" Thus, this study examines gender differences has been maintained if it is controlled their generation and academic discipline.

The purpose of this study is to examine the differences in research scholarship between male and female academics and to analyze these differences with a comparative perspective in terms of academic generation and academic disciplines. The issues addressed regarding gender in the subsequent analysis are largely determined by themes covered in the CAP questionnaire surveys.

Specifically, this research asks:

- What are the individual and institutional profiles of male and female academics?

- How much do male/female academics differ with respect to their research scholarship?

- Are these gender differences common in terms of academics' generation?

- Does academic discipline have an impact on male and female academics' research scholarship?

\section{Literature Review}

\section{Individual and Institutional Profiles among Male and Female academics}

Gender issues in academia vary from those about previous educational backgrounds and experiences to current teaching and research activities and working conditions. According to 
previous studies, male and female academics have slightly different profiles, not only in terms of educational background but also employed institutions. These profiles need to be examined because factors such as employment status have an impact on academics' perception and the practice of their work. This section briefly reviews the main profile issues.

First of all, women are less likely than men to hold a doctoral degree, and they have fewer years of academic experience than men. For instance, the proportion of Japanese academics holding a $\mathrm{PhD}$ degree was 60 percent male and 25 percent female in 1992. There was a change of this proportion to 75 percent male and 50 percent female in 2008; however, male academics still held a higher proportion of doctoral degrees (Arimoto, 2009). Toutkoushian and Bellas (2003) explain that controlling for differences between men and women academics concerning educational attainment greatly reduces the gender difference in employment.

Second, there have been studies regarding faculty employment status that has mainly looked at part-time versus full-time positions. Men are more likely to be in secure, tenured positions, whereas a higher proportion of women have contract, short-term, or part-time placements (Poole et al., 1997). Among academics in England, the higher the grade, the higher the proportion of male academics with full-time contracts and the fewer women there are. Among women, the proportion with full-time positions was 37 percent, while the proportion with part-time positions was 53 percent (Locke, 2008). However, as Toutkoushian and Bellas (2003) indicate that it is unclear whether the greater percentage of women with part-time employment reflects individual preferences or responses to blocked opportunities and discrimination.

Third, male academics tend to have more experience with international mobility than women, though there is lack of studies about gender differences regarding internationalization. Poole et al. (1997) have proven that there exist gender differences in terms of internationalization experience among academics after professorship, explaining that men are given greater access to travel abroad and research-related internationalization.

Fourth, a greater proportion of male academics are part of research-oriented universities, whereas more female academics work at teaching-oriented universities or other types of higher-education institutions. For instance, when the ratio of women faculty is compared among university types in Japan, the proportion at research universities is lowest (6 percent) and is highest at private non-research universities (10 percent), even though the proportion of women faculty in all universities has increased in the past fifteen years (Daizen \& Yamanoi, 2008). As well, in the case of Hong Kong, Postiglione and Tang (2008) state that within type 1 institutions (research oriented), about three-fourths (73 percent) of the respondents were men, compared to men making up about three-fifths (62 percent) of respondents at other institutions. Institutional type of female academics' shows contrast results.

\section{Research Scholarship among Male and Female academics}

Though all faculty members are expected to teach, research, and do service, currently the decisive factor in tenure and promotion decisions is research. Thus, issues in academics tend to emphasize research activities. In this study, the main gender issues are discussed 
specifically in terms of research scholarship. As well, the term "research scholarship" is used broadly to include not only research productivity but also perception of research and actual research activities.

It has been stated that women academics have "less time, energy, and commitment to invest in their professional careers and are therefore less productive scientifically than men" (Toren, 1993). The implication is that women are less oriented to research. Women are also perceived as being less concerned with, or as under utilizing, institutional resources (Davis \& Astin, 1990). As well, in the CAP survey results, interests in teaching and research have been shown to be different between male and female academics. For instance, in Argentina, women coincide with the general mean, while men prefer research activity ( 9 percent) or "both with a leaning towards research" (49 percent). The difference between the two options exceeds the general mean by seven points (Marquina \& Lamarra, 2008).

This pattern is also revealed in terms of workload. Men, as a group, devote a higher portion of their time than women to research activities, whereas women, as a group, devote a much higher percentage of their time than men to teaching and service activities (Park, 1996). Female faculty members are more likely than their male counterparts to be involved in undergraduate teaching and service and, consequently, are less engaged in research (Mamiseishvili \& Rosser, 2011).

These preferences and time investment are directly related to research productivity (Shin \& Cummings, 2010). Women academics publish less than men academics (Bellas \& Toutkoushian, 1999; Sax et al., 2002; Toutkoushian \& Conley, 2005). In 1979, Cole reported that men averaged 12.6 publications, compared to 7.6 for women (Cole, 1979). A decade later, the gender gap in publishing rates remained significant. From 1986 to 1988, men published almost twice as many articles and books as women. In 1989, 35 percent of men, but only thirteen percent of women, had published eleven more articles in professional journals, and 49 percent of men, but only 36 percent of women, had ever published or edited a book (Boyer, 1992). Toren (1993) and Billard (1993) report that women college and university faculty members publish much less than their male counterparts, that these women's scholarly work is generally regarded as being of a lower quality, and that they are rarely cited as having made scholarly contributions. The most recent study of Horta et al., (2012) specifically indicates that men produce $8 \%$ more articles in refereed journals than women in USA but no gender differences are perceived in the other types of outputs. In addition, according to current research by Postiglione and Jung (2012), who studied top-tier researchers in Asia, approximately 90 percent of highly productive researchers are male academics.

This state of affairs is also significant in terms of differences in research collaboration patterns. Building relationships with co-workers can be a challenge for women academics (Aguirre, 2000). For instance, O'Leary and Mitchell (1990) report that "even those women who did attend meetings reported fewer productive conversations leading to collaboration compared to men." They also report on the existence of an "invisible college," an old-boy network whose members "functioned as gatekeepers, controlling finances, reputations, and the fate of new scientific ideas." As well, women academics have been found "to be less well integrated into their academic departments and disciplines than men" because they lack 
mentors and networks, which assist in professional integration and productivity (O'Leary \& Mitchell, 1990).

\section{Gender Issues concerning Academic Generation and Academic Disciplines}

Based on previous studies regarding gender and research performance, this study raises the question, "Are male academics always are more productive than female academics in terms of research scholarship?" Davis and Astin (1990) raise questions about the subtle biases and contextual factors that affect scholarship for men and women. Thus, this study tried to include contextual factors that influence gender differences between male and female academics. To do this, it started with two questions. First, is the productivity gap between male and female groups the same regardless of rank? In the current system, there are many male academics in senior positions due to the history of the academic job market. In the past, the number of female academics was not high, and their academic experience was weaker than that of male academics. However, the educational level of female academics has been considerably enhanced, and the labour market of female academics has expanded over the last decades. Thus, we can currently find many female academics in junior positions.

Differences between women and men in terms of years of experience have led to further reductions in the gender gap. In addition, publication rates among women faculty have increased significantly in recent decades (Sax et al., 2002), and there has been some narrowing of the gender gap over time (Ward \& Grant, 1996). Generations are highly relevant in academia because academic identity, scholarship, and interpersonal relationships can change according to one's position or length of service. For instance, seniority is a significant factor in academic careers; the behaviour and performance of academics is recognized through their networks, resources, and their power within their higher-education institution and within the academic community at large (Jung, Kooji, \& Teichler, 2012).

This can be shown in several ways. In Finland, it is common to have more men than women in higher academic posts, but in lower academic posts, the proportions are inverted. For example, in universities of applied sciences, slightly less than one-fourth ( 24 percent) of professors are female, yet 41 percent of principal lectures and 63 percent of lectures are female (Aarrevaara \& Holtta, 2008). As well, in Australia, 85 percent of males are currently employed full time, through part-time employment is somewhat more common for female Australian academics (nineteen percent versus seven percent). Regarding their contracts, both are permanently employed, being either tenured (50 percent) or working on a continuous basis (twelve percent). However, in terms of rank, Australian male academics are more likely to occupy higher academic ranks than female academics. In Japan in 1992, 92 percent of all faculty members were male. In addition, there were fewer female faculty members in research universities and in upper ranks across all institutions. And while women's representation in universities has improved substantially since 1995, only five percent of Japanese faculty were women (Daizen \& Yamanoi, 2008). Therefore, this study conducted separate analyses for senior and junior faculty.

The second question asked in order to look at contextual factors that influence gender differences between male and female academics was the following: is the gap in productivity 
between males and females related to academic discipline? It is generally accepted that the proportion of male academics is higher in hard disciplines (e.g., engineering and the natural sciences), while the proportion of female academics is higher in soft disciplines (e.g., the humanities and education). In addition, the fact that research productivity in hard disciplines is usually higher than that in soft discipline is known through previous empirical studies. This study raises the question of whether the differences in research scholarship are maintained when it is controlled by academics' generation and discipline.

Interestingly, the differences in the composition of male and female faculty between fields explain virtually none of the gender differences (Toutkoushian \& Bellas, 2003). For instance, women are markedly most absent from the sciences. Their percentage of the work force is lowest in these disciplines and institutions. For women in these fields to be successful, their interest in publishing research and their competence in conducting successful research need to be extraordinarily high in order to survive in these male-dominated fields (Blackburn \& Bentley, 1993). According to Bellas (1997), for faculty in highly feminized disciplines in which the work is already devalued, it is plausible that the notion of comparable worth may influence perceptions of the unfair and inequitable institutional treatment of female faculty.

\section{Method}

\section{Data and Target groups}

This study uses data from an international comparative survey entitled "The Changing Academic Profession," conducted in 2007-2008 (RIHE, 2008). This is a second such international survey. The first was coordinated in 1993 by the Carnegie Foundation for the Advancement of Teaching. The second included nineteen higher-education systems. The survey questionnaire is composed of over 200 questions about demographics; academic career; perception of scholarship; workloads; perception of work environment; attitudes toward teaching, research, and institution; and a series of academic issues.

To examine gender differences in the research scholarship of academics, five countries were selected among nineteen with higher-education systems. The selection of a target group was conducted by the following processes. First, countries that had a sample size of more than 1,000 were selected for analysis. Second, to confirm which countries could explain gender issues reasonably, the proportion of female academics was compared between participating countries. As Figure 1 shows, the proportion of female academics is significantly different between countries. Fifty-nine percent of academics are female in Argentina, and 57 percent of them are female in Australia, while only seventeen percent of academics are female in Japan, and eighteen percent of them are female in Korea. To reduce bias from imbalance of cases, only countries that had approximately 40 percent of academics who were female were selected. 


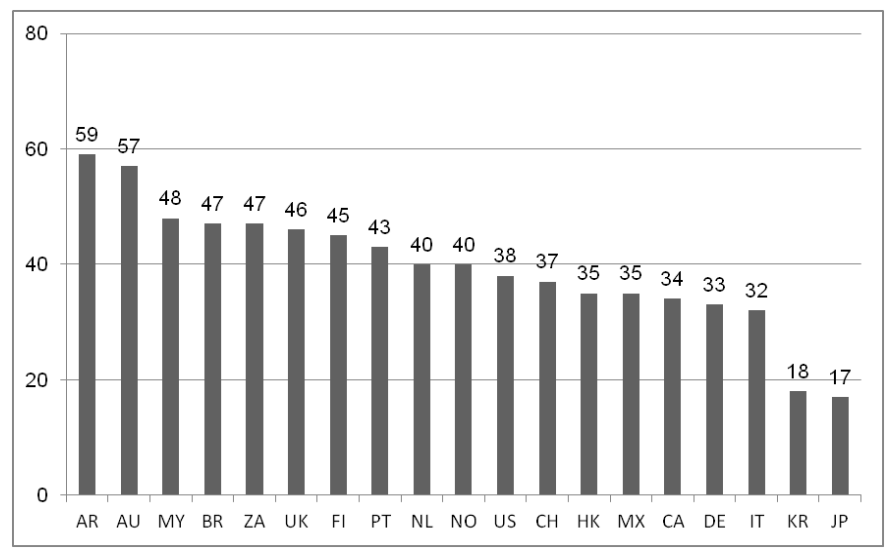

Figure 1. Proportion of female academics in nineteen higher education systems (Source: CAP, 2008)

Note. AR: Argentina, AU: Australia, MY: Malaysia, BR: Brazil, ZA: South Africa, UK: United Kingdom, FI: Finland, PT: Portugal, NL, Netherland, NO: Norway, US: Untied States, CH: China, HK: Hong Kong, MX: Mexico, CA: Canada, IT: Italy, KR: Korea, JP: Japan

Third, it was assumed that the academic-scholarship pattern would be different according to each national context; therefore, one country was chosen from each continent, including Asia-Pacific, North America, Latin America, and Europe. Based on these three criteria, the target group for analysis in this study was chosen to be China, Australia, the USA, Brazil, and the UK. Table 1 shows data collection and sample in each target group.

Table 1. Data collection \& Sample

\begin{tabular}{|c|c|c|c|c|}
\hline Australia & Brazil & China & United Kingdom & Untied States \\
\hline $\begin{array}{l}-5496 \text { e-mail surveys in } \\
22 \text { institutions } \\
-1252 \text { completed } \\
-24.2 \% \text { response rate }\end{array}$ & $\begin{array}{l}-5000 \text { e-mail surveys } \\
-1200 \text { completed } \\
-25.5 \% \text { response rate }\end{array}$ & $\begin{array}{l}\text { - Paper survey } \\
\text { questionnaire in } 70 \\
\text { institutions } \\
\text { (10 under central \& } 60 \\
\text { under local) } \\
-4200 \text { completed } \\
-85 \% \text { response rate }\end{array}$ & $\begin{array}{l}-1667 \text { completed } \\
-15 \% \text { response rate }\end{array}$ & $\begin{array}{l}-5065 \text { e-mail surveys } \\
-1048 \text { completed } \\
-20.7 \% \text { response rate }\end{array}$ \\
\hline
\end{tabular}

\section{Variables and Measurement}

This study will analyze the main differences in research scholarship between male and female academics, as well as whether these differences continue if generation and academic disciplines are controlled. First, their profile differences are compared in terms of educational background, such as holding a doctoral degree, and institutional background, such as the type of institution at which they work. Before these academics' research activities are studied, the profile analysis is examined in order to look at whether gender differences are inherent before professorship. Second, to examine and compare research scholarship, this study identifies research scholarship using six dimensions: research preference, time allocation for research, research productivity, research funding, research collaboration, and research service activities. These are based on literature reviews and all available data. Third, to examine gender in terms of differences in generation and academic discipline, academic discipline is classified into two categories based on Biglan (1973) — hard and soft — and academic generation is categorized as being senior or junior. 
More specifically, regarding academic generation, the respondents are classified according to status in the subsequent analysis. In this framework, we adopt the classification employed in the CAP project: senior academics, or "professors," on the one hand-i.e., those occupying a position equivalent to associate professors and full professors in the US highereducation system - and junior academics, or "junior staff," on the other hand-i.e., those in a lower position, such as assistant professors, lecturers, research associates, and assistants. As well, this study employs one of the criteria of Biglan (1973): the classification of hard and soft disciplines based on a well-defined paradigm structure. For instance, disciplines that have accumulative and obvious theory, such as the natural sciences, engineering, and medical science, are categorized as hard disciplines, whereas disciplines that have less-defined paradigm structures, such as the humanities, the social sciences, and business, are categorized as soft disciplines. Table 2 shows these variables.

Table 2. Variables and measurements

\begin{tabular}{lll}
\hline & Variables & \\
\hline Independent variables & & Measurement \\
\hline Gender & & Male=1, Female=2 \\
\hline Generation & & Senior=1, Junior=2 \\
\hline Academic discipline & & Hard=1, Soft=2 \\
\hline Dependent variables & Holding doctoral degree & \\
\hline Individual profile & International mobility experience & Yes=1, No=2 \\
Employment condition & Full-time=1, part-time=2 \\
\hline Institutional profile & Types of current institution & Universities: 1, Other HE institutions: 2 \\
\hline Research preference & & Preference for research=1, Teaching=2 \\
\hline Time allocation for research & & Average hours per week \\
\hline Research productivity & Books, articles, conference, reports granted & Number of papers in previous 3 years \\
\hline Research funding source & Institution, public, and private & \\
\hline Research collaboration & Institutional, International & Percentage (\%) of each funding source \\
\hline Research services & Peer review for articles, Journal editor work & Yes=1, No=2 \\
\hline
\end{tabular}

\section{Analysis}

In this study, gender differences in research scholarship among academics are examined. To compare two groups-male and female academics-descriptive statistics and t-tests are chiefly used. This study includes a comparison, using descriptive analysis, of patterns related to gender differences between countries. In addition, it includes an investigation into whether these differences are maintained regardless of academic generation and discipline. In the last section of this study, analysis is conducted that separates the dataset by academic generation (senior and junior) and discipline (hard and soft). 


\section{Findings and Discussions}

\section{Individual and Institutional Profiles among Male and Female Academics}

In this study, the gender differences of individual and institutional profiles of academics are examined. This examination looks at whether variations between academics of different genders are the inherent result of their backgrounds rather than a consequence of their current performance level.

Concerning the academics' gender, the proportion of male academics with doctorates is higher than that of female academics with doctorates. As Table 3 shows, this pattern is common across all countries. There are substantial variations, however, between countries. These include higher proportions of doctorate academics in the USA, Australia, and the UK, whereas this proportion is significantly lower in China and Brazil. In particular, the gender gap in the USA and Brazil (less than five percent) is not high, while this pattern is considerably higher in China (male: 37 percent vs. female: 21 percent).

This finding is similar to that of international mobility experiences. In this study, the definition of international mobility experience includes immigration and travelling for study. The male academics in this study had been more internationally mobile throughout their lives and careers than the female academics, except in the case of the UK. This gap is significant in the Australian sample. However, in the case of China, the proportion of international mobility experience itself is not high in terms of gender.

When we consider the employment status of the two genders, a less-favorable employment environment is observed for female academics. Except in the USA, the proportion of part-time work among female academics is much higher than that of male academics. This factor is substantial in Australia and the UK. For instance, five percent of male academics in the UK are employed part time, while eighteen percent of female academics hold part-time positions.

This employment situation is also apparent when looking at institutional types. When we categorize institutional types into universities and other types of higher-education institutions, the proportion of full-time employees among male academics is broadly higher than that of female academics across the five countries. However, this gap is not significant.

Table 3. Individual and institutional profiles among male and female academics: An international comparison

\begin{tabular}{|c|c|c|c|c|c|c|c|c|c|c|c|}
\hline & \multicolumn{2}{|c|}{$\mathrm{AU}$} & \multicolumn{2}{|c|}{$\mathrm{BR}$} & \multicolumn{2}{|c|}{$\mathrm{CH}$} & \multicolumn{2}{|c|}{ UK } & \multicolumn{2}{|c|}{ US } & \multirow{2}{*}{ Summary } \\
\hline & $\mathrm{M}$ & $\mathrm{F}$ & $\mathrm{M}$ & $\mathrm{F}$ & $\mathrm{M}$ & $\mathrm{F}$ & $\mathrm{M}$ & $\mathrm{F}$ & $\mathrm{M}$ & $F$ & \\
\hline Doctorate $(\%)$ & $\begin{array}{c}404 \\
(79.5)\end{array}$ & $\begin{array}{c}356 \\
(69.3)\end{array}$ & $\begin{array}{c}358 \\
(59.1)\end{array}$ & $\begin{array}{c}293 \\
(54.5)\end{array}$ & $\begin{array}{c}801 \\
(36.3)\end{array}$ & $\begin{array}{c}271 \\
(20.8)\end{array}$ & $\begin{array}{c}469 \\
(68.5)\end{array}$ & $\begin{array}{c}402 \\
(59.9)\end{array}$ & $\begin{array}{c}560 \\
(84.8)\end{array}$ & $\begin{array}{c}385 \\
(81.1)\end{array}$ & $\mathrm{M}>\mathrm{F}$ \\
\hline $\begin{array}{l}\text { International mobility } \\
\text { experience }(\%)\end{array}$ & $\begin{array}{c}246 \\
(52.0)\end{array}$ & $\begin{array}{c}182 \\
(38.0)\end{array}$ & $\begin{array}{c}81 \\
(14.6)\end{array}$ & $\begin{array}{c}50 \\
(10.0)\end{array}$ & $\begin{array}{c}54 \\
(3.1)\end{array}$ & $\begin{array}{c}22 \\
(2.1)\end{array}$ & $\begin{array}{c}129 \\
(23.7)\end{array}$ & $\begin{array}{c}146 \\
(27.7)\end{array}$ & $\begin{array}{c}151 \\
(23.1)\end{array}$ & $\begin{array}{c}71 \\
(15.2)\end{array}$ & $\begin{array}{c}\mathrm{M}>\mathrm{F} \\
\text { (except UK) }\end{array}$ \\
\hline $\begin{array}{l}\text { Contract: part-time } \\
(\%)\end{array}$ & $\begin{array}{c}34 \\
(6.7)\end{array}$ & $\begin{array}{c}101 \\
(19.8)\end{array}$ & $\begin{array}{c}269 \\
(44.6)\end{array}$ & $\begin{array}{c}257 \\
(48.0)\end{array}$ & $\begin{array}{c}73 \\
(3.4) \\
\end{array}$ & $\begin{array}{c}34 \\
(2.7)\end{array}$ & $\begin{array}{c}30 \\
(5.1)\end{array}$ & $\begin{array}{c}106 \\
(18.2)\end{array}$ & $\begin{array}{c}40 \\
(6.1)\end{array}$ & $\begin{array}{c}23 \\
(4.9)\end{array}$ & $\begin{array}{c}\mathrm{M}<\mathrm{F} \\
\text { (except US) }\end{array}$ \\
\hline $\begin{array}{l}\text { Institutional type: } \\
\text { University }(\%)\end{array}$ & $\begin{array}{c}348 \\
(68.5)\end{array}$ & $\begin{array}{c}358 \\
(69.6)\end{array}$ & $\begin{array}{c}298 \\
(49.7)\end{array}$ & $\begin{array}{c}254 \\
(47.4)\end{array}$ & $\begin{array}{l}1,878 \\
(85.2)\end{array}$ & $\begin{array}{l}1,093 \\
(83.9)\end{array}$ & $\begin{array}{c}521 \\
(92.7)\end{array}$ & $\begin{array}{c}518 \\
(94.5)\end{array}$ & $\begin{array}{c}487 \\
(73.8)\end{array}$ & $\begin{array}{c}352 \\
(74.1)\end{array}$ & - \\
\hline $\mathrm{N}$ & $\begin{array}{c}508 \\
(37.1)\end{array}$ & $\begin{array}{c}514 \\
(37.5)\end{array}$ & $\begin{array}{c}606 \\
(52.8)\end{array}$ & $\begin{array}{c}538 \\
(46.9)\end{array}$ & $\begin{array}{c}2205 \\
(61.0)\end{array}$ & $\begin{array}{c}1302 \\
(36.0)\end{array}$ & $\begin{array}{c}685 \\
(43.8)\end{array}$ & $\begin{array}{c}671 \\
(42.9)\end{array}$ & $\begin{array}{c}660 \\
(57.6)\end{array}$ & $\begin{array}{c}475 \\
(41.4)\end{array}$ & \\
\hline
\end{tabular}

- $\quad$ M: male, F: Female

- $\quad$ AU: Australia, BR: Brazil, CH: China, UK: United Kingdom, US: United States of America 
- International mobility: including foreign born, early immigrant foreigners, early immigrant citizens, $\mathrm{PhD}$ immigrant foreigners, $\mathrm{PhD}$ immigrant citizens, Professional migrant citizens, Study mobile academics, and PhD mobile academics

(Source: CAP, 2008)

\section{Gender Differences in Research Scholarship among Academics}

Six aspects of academics' research scholarship have been addressed in this study.

- (a) Preference for research (compared with teaching)

- (b) Time allocation for research per week

- (c) Research publications: (co-)authored book, (co-)edited book, journal article, report from funded project, or conference presentation

- (d) Research funding: funding source from own institution, public agency, or private agency

- (e) Research collaboration: institutional, international collaboration

- (f) Research service activities: peer reviewer, journal editor

A short glance at Table 4 suggests that the pattern of research scholarship between male and female academics is different in many ways. In particular, these differences are highly significant in terms of research publication, research funding, and research collaboration rather than in terms of individual perception, such as preference or individual effort-for instance, time allocation.

Of the respondents, male academics prefer research more than do female academics across countries. Even though there is no significant gender difference in Australia and Brazil, this difference is significant in China, the UK, and the USA. In particular, 56 percent of male academics prefer research over teaching, while only 31 percent of female academics show the same preference. In USA, 48 percent of male academics prefer research, and 39 percent of female academics prefer research over teaching scholarship. This may be one of reasons why the proportion of female academics in teaching-intensive universities is higher than that of male academics in such universities, while the proportion of male academics working in research-intensive universities is higher than that of female academics.

A similar phenomenon is observed concerning the actual allocation of working time. On average, male academics differ from women academics regarding the time they allocate to research. These gaps are different across countries, from being only 0.1 hours to four hours per week. Again, research preference and time allocation for research need to be compared in terms of current institutional types.

In addition, the number of publications published by male and female academics in the past three years is compared. The data suggest that gender does affect academic productivity. Male academics' productivity is higher than that in the junior group across publication types and countries, except book publication. In particular, this gap is highly significant with regard to journal articles and conference presentations.

Also, concerning research funding, it is found that the main research funding sources are different between male and female academics across countries. A substantial proportion of female academics obtain research funding from their own institution rather than from outside, 
including through public or private agency. By contrast, male academics tend to rely on more diverse funding sources.

Next, we note that the proportion of research collaboration is considerably different between male and female academics across countries, particularly in terms of international research collaboration. It could be assumed that male academics have participated in more collaborations not only in terms of inter-institution collaborations but also in terms of international collaborations.

Lastly, regarding research service activities, such as peer-review and journal-editing work, male academics are highly involved in these service activities. In particular, in the case of female academics in China, only seven percent and three percent of academics responded that they had done peer-review work and journal-editing work.

Table 4. Gender differences in research scholarship among academics: An international comparison

\begin{tabular}{|c|c|c|c|c|c|c|c|c|c|c|}
\hline & \multicolumn{2}{|c|}{$\mathrm{AU}$} & \multicolumn{2}{|c|}{$\mathrm{BR}$} & \multicolumn{2}{|c|}{$\mathrm{CH}$} & \multicolumn{2}{|c|}{ UK } & \multicolumn{2}{|c|}{ US } \\
\hline & M & $\mathrm{F}$ & M & $\mathrm{F}$ & M & $\mathrm{F}$ & M & $\mathrm{F}$ & M & $\mathrm{F}$ \\
\hline \multicolumn{11}{|l|}{ Preference } \\
\hline Research $>$ Teaching & 71.8 & 67.6 & 46.9 & 49.0 & $56.3^{* * *}$ & 30.7 & $70.7 *$ & 63.2 & $47.9 *$ & 39.0 \\
\hline \multicolumn{11}{|c|}{ Time allocation (per week) } \\
\hline Research & $15.1^{*}$ & 13.2 & 9.0 & 8.9 & $15.0 * * *$ & 11.0 & $14.3 * * *$ & 10.0 & $13.7 * * *$ & 10.6 \\
\hline \multicolumn{11}{|l|}{ Publications } \\
\hline (Co) Authored Books & 0.3 & 0.3 & 0.5 & 0.6 & $0.9^{*}$ & 0.7 & $0.5^{* *}$ & 0.3 & 0.3 & 0.2 \\
\hline (Co) Edited books & 0.2 & 0.2 & $0.3^{*}$ & 0.2 & 0.8 & 0.9 & $0.4^{*}$ & 0.3 & 0.2 & 0.3 \\
\hline Journal articles & $8.5^{* * * *}$ & 5.9 & $5.1 * * *$ & 3.8 & $9.5 * * *$ & 6.3 & $7.8 * * *$ & 4.7 & $4.8^{*}$ & 3.6 \\
\hline $\begin{array}{l}\text { Report from funded } \\
\text { project }\end{array}$ & 1.5 & 1.5 & 1.4 & 1.4 & $1.6^{*}$ & 1.1 & $1.6^{* * *}$ & 0.9 & $1.5^{* * *}$ & 0.8 \\
\hline $\begin{array}{l}\text { Conference } \\
\text { presentation }\end{array}$ & 5.9 & 5.7 & $6.2 *$ & 4.8 & $2.9 * * *$ & 1.9 & $6.5^{* * * *}$ & 5.0 & 6.1 & 5.2 \\
\hline \multicolumn{11}{|c|}{ Research funding sources (\%) } \\
\hline Own institution & 36.2 & $40.6^{*}$ & 15.4 & $19.1 * * *$ & 40.9 & $50.1 * * *$ & 36.5 & $44.4^{*}$ & 50.6 & $52.3^{*}$ \\
\hline Public agency & 44.6 & 42.1 & 27.2 & 24.6 & $37.6^{*}$ & 32.7 & 45.2 & 38.3 & $25.6^{* * *}$ & 16.2 \\
\hline Private agency & 12.9 & 13.8 & $6.1^{*}$ & 4.4 & - & - & 14.0 & 12.6 & 13.9 & 14.4 \\
\hline \multicolumn{11}{|c|}{ Research collaboration $(\%)$} \\
\hline Institutional & 67.4 & 66.3 & $68.2 * * *$ & 50.4 & $38.8 * * *$ & 31.5 & $72.0 * *$ & 62.5 & 63.4 & 56.2 \\
\hline International & $64.9 * * *$ & 53.4 & $37.2^{* * *}$ & 18.8 & $14.8^{* * *}$ & 8.3 & $68.5^{* * *}$ & 53.3 & $36.7 *$ & 27.9 \\
\hline \multicolumn{11}{|l|}{ Research activities (\%) } \\
\hline Peer-reviewer & $75.0 * * *$ & 69.3 & 52.2 & 47.4 & $20.2 * * *$ & 6.8 & $74.7 * * *$ & 64.9 & $69.1^{*}$ & 62.0 \\
\hline Journal/Book editor & 22.5 & 18.6 & $23.0 * *$ & 15.8 & 6.9 & 3.0 & $28.0 * *$ & 20.4 & 21.5 & 17.1 \\
\hline $\mathrm{N}$ & 478 & 471 & 438 & 409 & 1228 & 560 & 437 & 419 & 609 & 424 \\
\hline
\end{tabular}


- $\quad$ Preference, Research collaboration (\%), Academic service (\%): Chi-square

\section{Gender Differences in Research Scholarship among Academics by Generation and Discipline}

As Figures 2 and 3 show, the proportions of male academics in senior ranks and in hard disciplines is higher than those of female academics.

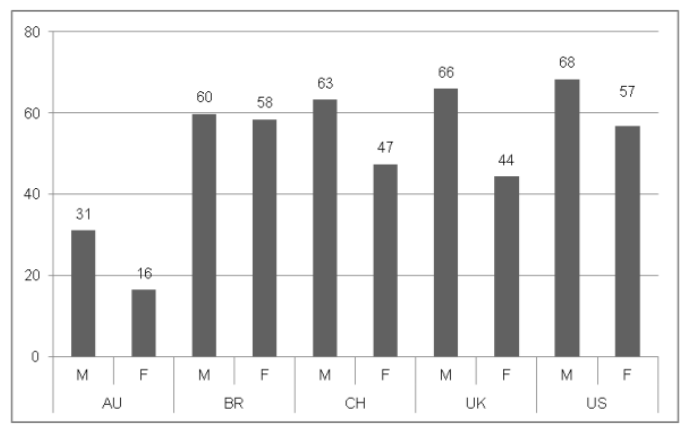

Figure 2. Gender distribution and rank (Senior position)

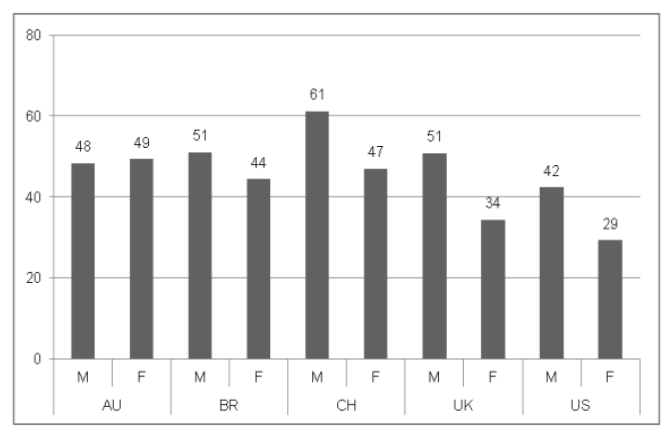

Figure 3. Gender distribution and academic discipline (Hard discipline)

As a final step in the analysis, we aimed to establish whether academic generation and discipline affect the research scholarship of academics differently in terms of gender. For this purpose, one country (USA) was selected, and the analysis was conducted with separate samples regarding generation (senior and junior) and discipline (hard and soft). The findings are documented in Table 5.

As regards generation, if it was analyzed separately, gender differences are weaker than it was done with whole sample. In particular, there is no significant difference between genders among junior academics in terms of time allocation for research. As well, the research-productivity gap between genders is not significant in the junior group except with regard to reports from funded projects. However, regarding research funding sources, male academics still receive a higher proportion of research funding from public agencies. In addition, among male academics, international collaboration and participation as a journal reviewer is significant higher than among female academics in the junior group.

In terms of academic discipline, the gender gap is still large in hard disciplines; however, these differences scarcely appear in soft disciplines. For instance, in hard disciplines, gender differences from the whole sample group are almost maintained, including those concerning time for research, research publications, research funding, research collaboration, and service activities. However, gender difference in terms of the number of articles published, which is the most powerful research performance indicator, is weaker if it is controlled by academic discipline. In particular, in soft disciplines, gender differences are rare except with regard to generating reports from funded projects and funding from public agencies. 
Table 5. Gender differences in research scholarship among academics by rank and discipline (only USA)

\begin{tabular}{|c|c|c|c|c|c|}
\hline & \multirow[t]{2}{*}{ Gender } & \multicolumn{2}{|c|}{$\begin{array}{l}\text { Gender \& } \\
\text { Rank }\end{array}$} & \multicolumn{2}{|c|}{$\begin{array}{l}\text { Gender \& } \\
\text { Discipline }\end{array}$} \\
\hline & & Senior & Junior & Hard & Soft \\
\hline \multicolumn{6}{|l|}{ Preference } \\
\hline Research $>$ Teaching & $\mathrm{M}>\mathrm{F}^{*}$ & & $\mathrm{M}>\mathrm{F}^{*}$ & $\mathrm{M}>\mathrm{F}^{*}$ & \\
\hline \multicolumn{6}{|l|}{ Time allocation } \\
\hline Research & $\mathrm{M}>\mathrm{F}^{* * * *}$ & & & & \\
\hline \multicolumn{6}{|l|}{ Publications } \\
\hline $\begin{array}{l}\text { (Co) Authored Books } \\
\text { (Co) Edited books }\end{array}$ & & $\mathrm{M}>\mathrm{F}^{*}$ & & $\mathrm{M}>\mathrm{F}^{*}$ & \\
\hline Journal articles & $\mathrm{M}>\mathrm{F}^{*}$ & $\mathrm{M}>\mathrm{F}^{*}$ & & & \\
\hline Report from funded project & $\mathrm{M}>\mathrm{F}^{* * *} *$ & $\mathrm{M}>\mathrm{F}^{* * *}$ & $\mathrm{M}>\mathrm{F}^{*}$ & $\mathrm{M}>\mathrm{F}^{*}$ & $\mathrm{M}>\mathrm{F}^{*}$ \\
\hline \multicolumn{6}{|l|}{ Conference presentation } \\
\hline \multicolumn{6}{|l|}{ Research funding sources (\%) } \\
\hline Own institution & & $\mathrm{M}<\mathrm{F}^{*}$ & & $\mathrm{M}<\mathrm{F}^{*}$ & \\
\hline Public agency & $\mathrm{M}>\mathrm{F}^{* * * *}$ & $\mathrm{M}>\mathrm{F}^{* * *}$ & $\mathrm{M}>\mathrm{F}^{*}$ & & $\mathrm{M}>\mathrm{F}^{*}$ \\
\hline \multicolumn{6}{|l|}{ Private agency } \\
\hline \multicolumn{6}{|l|}{ Research collaboration $(\%)$} \\
\hline \multicolumn{6}{|l|}{ Institutional } \\
\hline International & $\mathrm{M}>\mathrm{F}^{*}$ & $\mathrm{M}>\mathrm{F}^{*}$ & & $\mathrm{M}>\mathrm{F}^{*}$ & \\
\hline \multicolumn{6}{|l|}{ Research activities (\%) } \\
\hline Peer-reviewer & $\mathrm{M}>\mathrm{F}^{*}$ & & $\mathrm{M}>\mathrm{F}^{*}$ & $\mathrm{M}>\mathrm{F}^{* *}$ & \\
\hline Journal/Book editor & & & & $\mathrm{M}>\mathrm{F}^{*}$ & \\
\hline
\end{tabular}

\section{Discussions}

Based on the main results above, some discussion points are presented. First of all, as the results show, there exist variances in gender distribution in terms of the proportion of female academics, their working conditions, and their productivity across countries. Detailed analysis is needed regarding gender issues, with consideration of the context of each country. Although there are differences of variance to explain of gender differences, there are common gender issues to be found across countries.

One common issue is that there still exist differences between genders in terms of their educational background, employment status, and working institution. A higher proportion of male academics holds doctoral degree and has more international experience. Also, a higher proportion of male academics hold full-time positions and work in research universities, compared to female academics. These results are aligned with previous studies about the backgrounds and working conditions of female academics (Kirshstein et al., 1997). Although there has been much progress in the job market for female academics, it is still common for male academics to have preferable working conditions. This is confirmed by their research 
scholarship: male academics tend to be more active in research scholarship, particularly in terms of performance, collaboration, funding, and research service. Teodorescu (2000) indicates that women receive fewer grants than men do and are employed disproportionately in disciplines that have an article productivity that is lower than average. As well, numerous studies have proven that male academics are highly involved in research scholarship.

Numerous hypotheses have tried to explain these differences in terms of biological, cultural, structural, and psychological factors. For instance, these differences in research productivity have been explained as being the result of women's structural positions in universities: women carry heavier teaching loads, bear greater responsibility for undergraduate education, and have more service commitments (Park, 1996). Women also have less access to graduate teaching assistants, travel funds, research money, laboratory equipment, and release time for research. Some studies claim that women are simply not socialized to be career oriented or ambitious to the same degree as men. Certain tasks, such as managing money, may be considered more masculine, whereas other tasks, such as dealing with clients, may be considered more feminine, thus replicating gender stereotypes that exist outside the corporation (Park, 1996).

However, this study considers contextual variables such as academic generation and discipline. As a result, in the junior group, differences between genders are lower than those in the senior group, particularly with regard to research preference, research efforts, and publications. As well, many research-activity patterns between male and female academics are not significant in soft disciplines, which have more female academics than hard disciplines. In other words, the gender gap has recently decreased in academia since more female academics are involved in research scholarship with professional career.

Still, when considering research funding sources and collaboration, there are significant differences between genders. Male academics receive much more funding than female academics. Also, male academics participate much more in collaborations, even when academic discipline is controlled. This collaboration pattern is ultimately related to research performance, given that research collaboration is highly correlated with research productivity Katz, \& Martin, 1997). This discussion touches on issues regarding the strength or weakness of academic networks among male and female academics. According to O'Leary and Mitchell (1990), while women have networks, they do not benefit these women professionally: "women who reported low connectedness with the old boy network saw themselves as operating on the periphery of their disciplines which resulted in difficulty in obtaining resources for their work, getting published, and earning recognition." Also, international reputations are established by "attending conferences, publishing, giving presentations and organizing and participating in symposia" (O'Leary \& Mitchell, 1990). Still, it needs to be examined in detail with regard to academic.

\section{Conclusion}

As more women enter academia, there has been growing interest in examining the range of their academic activities. Despite recent and significant gains made by academic women, they still comprise only a small proportion of academics and remain under-represented at 
prestigious institutions and in higher faculty ranks. To understand their scholarship and optimize academic profession, the source of these differences needs to be clarified. This study examined the differences in research scholarship between male and female academics and explored contextual factors associated with their scholarship.

The main results can be summarized as follows. Male academics still hold a higher proportion of doctoral degrees, have more international mobility experience, and have a better employment status and working conditions than female academics. Regarding research scholarship, male academics have more involvement than female academics. Male academics prefer research, invest much more time in research, have higher publication, have diverse funding sources, and are involved in a greater number of international collaborations and academic service activities. These trends are common across countries, even though the proportions are different. However, when the dataset is examined based on academic generation and academic discipline, we find slightly different results. The gaps are stronger in the senior group than in the junior group: gender differences are reduced in the junior group. As well, regarding academic discipline, the differences are not significant among soft disciplines. These reduced gaps are relevant with regard to research preference, time allocation for research, and research productivity. Nevertheless, there is still less involvement by women academics with regard to research funding sources and research collaboration. Thus, while levels of female academics' efforts and outputs have improved in the last decades, women continue to have network-related issues: they shown less involvement in networks.

This study identified a number of variables important to research scholarship among male and female academics and raises a number of questions which would benefit from more research. Further, it might investigate several conjunctional research questions related with gender issues among academics. For instance, it is needed to include country case that has relatively low proportion of female academics in national level. As well, different types of workload such as teaching and service should be considered and examined to understand gender difference in scholarship. Concerning gender issues, an examination of female academics' scholarship should consider the variables of their institutional and national context and we need to understand the strengths and weakness of female academics in order to improve policy issues.

\section{References}

Aarrevaara, T., \& Holtta, S. (2008). Changes in the Finnish academic profession reflect reforms in higher education. In RIHE Research Institute for Higher Education. The changing academic profession in international comparative and quantitative perspectives. Hiroshima: Hiroshima University.

Arimoto, A. (2008). International implication of the changing academic profession in Japan. In RIHE Research Institute for Higher Education. The changing academic profession in international comparative and quantitative perspectives. Hiroshima: Hiroshima University.

Arimoto, A. (2009). Changing academic profession in the world from 1992 to 2007. In RIHE 
Research Institute for Higher Education. The changing academic profession over 19922007: International, comparative, and quantitative perspectives.

Baldwin, G. (1985). Women at Monash University. Monash, Australia: Monash University.

Bellas, M. L. (1994). Comparable worth in academia: The effects on faculty salaries of the sex composition and labor market conditions of academic disciplines. American Sociological Review, 59, 807-821.

Bellas, M. L. (1997). Disciplinary differences in faculty salaries: Does gender bias play a role? The Journal of Higher Education, 68(3), 299-321.

Bellas, M. L., \& Toutkoushian, R. K. (1999). Faculty time allocation and research productivity: Gender, race, and family effects. The Review of Higher education, 22(4), 367-390.

Biglan, A. (1973). Relationships between subject matter characteristics and the structure and output of university departments. Journal of Applied Psychology, 57(3), 204-213.

Billard, L. (1994). Twenty years later: Is there parity for Academic women? Thought and Action, 10, 115-144.

Blackburn, R. T., \& Bently, R. J. (1993). Faculty research productivity: Some moderators of associated stressors. Research in Higher Education, 34, 725-745.

Bornstein, R. (2008). Women and the college presidency. In Gllazer-Raymo, J. (ed). Unfinished agendas: new and continuing gender challenges in higher education. The Johns Hopkins University Press.

Boyer, E. L. (1992). Scholarship Re-considered: Priorities of the professoriate, Princeton, N. J., : Carnegie Foundation for Advancement of Teaching.

Cole, J. R. (1979). Fair science: Women in the scientific community. New York: Free Press.

Daizen, T., \& Yamanoi, A. (2008). The changing academic profession in an era of university reform in Japan. In RIHE Research Institute for Higher Education. The changing academic profession in international comparative and quantitative perspectives. Hiroshima: Hiroshima University.

Davis, D. E., \& Astin, H.S. (1990). 'Life cycle, career patterns and gender stratification in academe: breaking myths and exposing truths', in Stiver Lie, S., and O'Leary, V.E. (eds.), Storming the Tower Women in the Academic World. London: Kogan Page; New York: Nichols/GP.

Finkelstein, M. \& Cummings, W. (2008). The Changing academic profession in the United States: 2007. In RIHE Research Institute for Higher Education. The changing academic profession in international comparative and quantitative perspectives. Hiroshima: Hiroshima University.

Gmelch, W. H., Wilke, P. K., \& Lovrich, N. P. (1986). Dimensions of stress among university faculty: factor-analytic results from a national study. Research in Higher Education 24: 266-286.

Hagedorn, L. S., \& Sax, L. J. (1999). Marriage, Children, and Aging Parents: The Role or Family-Related Factors in Faculty Job Satisfaction. Paper presented at the annual meeting of the American Educational Research Association, Montreal, Canada, April 1999. 
Horta, H., Dautel, V., \& Veloso, F. M. (2012). An output perspective on the teaching-research nexus: an analysis focusing on the United States higher education system. Studies in Higher Education, 37(2), 171-187.

Jung, J., Kooij, R., \& Teichler, U., (2012). Internationalization and the new academic generation. In Finkelstein, M., Huang, F., \& Rostan, M. (eds.) The Internationalization of the Academy: Changes, Realities and Prospects. Springer. (Forthcoming).

Katz, J. S., \& Martin, B. R. (1997). What is research collaboration? Research Policy, 26(1), $1-18$.

Keller, G. (2001). The new demographics of higher education. The Review of Higher Education, 24(3), 219-235.

Locke, W. (2008). The academic profession in England: still stratified after all these years? In RIHE Research Institute for Higher Education. The changing academic profession in international comparative and quantitative perspectives. Hiroshima: Hiroshima University.

Mamiseishvili, K., \& Rosser, V. J. (2011). Examining the relationship between faculty productivity and job satisfaction. The Journal of the Professoriate, 5(2), 68-100.

Marquina, M., \& Lamarra, N. F. (2008). The academic profession in Argentina: Characteristics and trends in the context of a mass higher education system. In RIHE Research Institute for Higher Education. The changing academic profession in international comparative and quantitative perspectives. Hiroshima: Hiroshima University.

Olsen, D., Maple, S., and Stage, F. (1995). Women and minority faculty job satisfaction. Higher Education, 66, 267-292.

O'Leary, V. E., \& Mitchell, J. M. (1990). 'Women connecting with women: networks and mentors in the United States', in Stiver Lie, S., and O'Leary, V.E. (eds.), Storming the Tower Women in the Academic World. London: Kogan Page; New York: Nichols/GP.

Park, S. M. (1996). Research, teaching, and service: Why shouldn't women's work count? The Journal of Higher Education, 67(1), 46-84.

Poole, M. E., \& Langan-Fox, J. (1996). Australian Women and Careers; Psychological and Contextual Influences over the Life Course. Cambridge University Press.

Poole, M., Bornholt, L., \& Summers, F. (1997). An international study of the gendered nature of academic work: Some cross-cultural explorations. Higher Education, 34, 373-396.

Postiglione, G., \& Jung, J. (2012). World-class university and Asia's top tier researchers. In Wang, Q., Cheng, Y., \& Liu, N. C., (eds.). Building World-Class Universities: Different Approaches to a Shared Goal. Sense Publisher (Forthcoming).

Postiglione, G., \& Tang, H. (2008). A preliminary review of the Hong Kong CAP data. In RIHE Research Institute for Higher Education. The changing academic profession in international comparative and quantitative perspectives. Hiroshima: Hiroshima University.

Preffer, J., \& Davis-Blake, A. (1987). The effects of the proportion of women on salaries: The case of college administration. Administrative Science Quarterly, 32, 1-24.

RIHE Research Institute for Higher Education. (2008). The changing academic profession in international comparative and quantitative perspectives. Hiroshima: Hiroshima University.

Sax, L. J., Hagedorn, L. S., Arredondo, M., \& Dicrisi III F. A. (2002). Faculty research productivity: Exploring the rope of gender and family-related factors. Research in Higher 
Education, 43(4), 423-446.

Shin, J. C., \& Cummings, W. K. (2010). Multi-level analysis of academic publishing across discipline: research performance, collaboration, and time on research. Scientometrics, $85(2), 582-594$.

Teodorescu, D. (2000). Correlates of faculty publication productivity: A cross-national analysis, Higher Education, 39(2), 201-222.

Toren, N. (1993). 'The temporal dimension of gender inequality in academia', Higher Education, 25, 439-455.

Toutkoushian, R. K., \& Bellas, M. L. (2003). The effects of part-time employment and gender on faculty earnings and satisfaction: Evidence from the NSOPF:93. The Journal of Higher Education, 74(2), 172-195.

Ward, K. B., \& Grant, L. (1996). Gender and academic publishing. In J. Smart (ed.), Higher Education: Handbook of Theory and Research, Vol. XI, pp. 172-212. Edison, NJ: Agathon. 